\title{
Geochemical studies of the Silurian oil reservoir in the Well Shun-9 prospect area, Tarim Basin, NW China
}

\author{
Song Daofu, Li Meijun and Wang T.-G* \\ State Key Laboratory of Petroleum Resources and Prospecting, China University of Petroleum, Beijing 102249, China \\ (C) China University of Petroleum (Beijing) and Springer-Verlag Berlin Heidelberg 2013
}

\begin{abstract}
Commercial oil flow has been obtained from the sandstone reservoir of the Lower Silurian Kelpintag Formation in the Well Shun-9 prospect area. In the present studies, 10 Silurian oil and oil sand samples from six wells in the area were analyzed for their molecular and carbon isotopic compositions, oil alteration (biodegradation), oil-source rock correlation and oil reservoir filling direction. All the Silurian oils and oil sands are characterized by low $\mathrm{Pr} / \mathrm{Ph}$ and $\mathrm{C}_{21} / \mathrm{C}_{23}$ tricyclic terpane $(<1.0)$ ratios, "V"-pattern $\mathrm{C}_{27}-\mathrm{C}_{29}$ steranes distribution, low $\mathrm{C}_{28}$-sterane and triaromatic dinosterane abundances and light $\delta^{13} \mathrm{C}$ values, which can be correlated well with the carbonate source rock of the $\mathrm{O}_{3} l$ Lianglitage Formation. Different oil biodegradation levels have also been confirmed for the different oils/oil sands intervals. With the $\mathrm{S}_{1} k^{2}$ seal, oils and oil sands from the $\mathrm{S}_{1} k^{1}$ interval of the Kelpintag Formation have only suffered light biodegradation as confirmed by the presence of "UCM" and absence of 25-norhopanes, whereas the $\mathrm{S}_{1} k^{3-1}$ oil sands were heavily biodegraded (proved by the presence of 25 -norhopanes) due to the lack of the $\mathrm{S}_{1} k^{2}$ seal, which suggests a significant role of the $\mathrm{S}_{1} k^{2}$ seal in the protection of the Silurian oil reservoir. Based on the $\mathrm{Ts} /(\mathrm{Ts}+\mathrm{Tm})$ and 4-/1-MDBT ratios as reservoir filling tracers, a general oil filling direction from NW to SE has been also estimated for the Silurian oil reservoir in the Well Shun-9 prospect area.
\end{abstract}

Key words: Silurian oil reservoir, Well Shun-9 prospect area, geochemistry, oil-source rock correlation, alteration, oil reservoir filing direction

\section{Introduction}

The Well Shun-9 prospect area is located at the south of the Shuntuoguole Low Uplift, Tarim Basin. After undergoing several years exploration and after sand fracturing operations, commercial oil flows have been obtained from the sandstone reservoirs of the Lower Silurian Kelpintag Formation at Wells Shun- $9,-901,-902 \mathrm{H}$ in the area in the last two years.

Silurian sandstones are widely distributed in the Shuntuoguole Low Uplift and its adjacent regions. As early as 1994, Silurian commercial oil was discovered in Well TZ11, in the Tazhong Uplift on the south of the Shuntuoguole Low Uplift (Zhai and Wang, 1999). Since then, the Silurian interval became one of the most important exploration targets (Zhang et al, 2004; Jia et al, 2006). As the first discovered Silurian oil reservoir in Shuntuoguole Low Uplift, studies on it are significant for oil exploration in the area.

In the present study, three oil and seven oil sand samples from the Silurian oil reservoir were collected from six exploration wells (sampling well location see Fig. 1) and analyzed in the laboratory for oil molecular and isotopic

*Corresponding author. email: wwttgg@aliyun.com

Received August 8, 2013 compositions. Alteration (biodegradation), oil-source rock correlation and oil filling orientation were deduced from the results.

\section{Geological setting}

The Shuntuoguole Low Uplift is in fact still a negative structure, being a relative uplift within a huge depression zone. The depression zone is composed of the Manjiaer and Awati Depressions as well as the Shuntuoguole Low Uplift in between. The Shuntuoguole Low Uplift is also located between the Tabei Uplift on the north and the Tazhong Uplift on the south (Fig. 1).

The Shuntuoguole Low Uplift occurred during early Paleozoic time and subsequently underwent multi-stage tectonic transformation. Compared with surrounding uplifts and depressions, however, the geological setting of the Shuntuoguole Low Uplift is more stable tectonically and more favorable for crude oil preservation (Xiong et al, 2013).

Regionally, the Lower-Middle Silurian strata are widespread and comprised of the $\mathrm{S}_{1} k$ Kelpintag, $\mathrm{S}_{1} t$ Tataertag and $\mathrm{S}_{1} y$ Yimugantawu Formations in the Shuntuoguole Low Uplift (Zhu et al, 2005; Jia et al, 2006; Fig. 2). As a principal reservoir interval, the $\mathrm{S}_{1} k$ Kelpintag Formation can be divided 
into three members; the $\mathrm{S}_{1} k^{1}$ lower sandstone, $\mathrm{S}_{1} k^{2}$ middle mudstone and $\mathrm{S}_{1} k^{3}$ upper sandstone members, while the $\mathrm{S}_{1} k^{3}$ upper member also can be subdivided into three sections, i.e., $\mathrm{S}_{1} k^{3-1}$ lower sandstone, $\mathrm{S}_{1} k^{3-2}$ middle mudstone and $\mathrm{S}_{1} k^{3-3}$ upper sandstone sections (Fig. 2). So far, however, the major Silurian reservoirs for movable oil production are only discovered within the $\mathrm{S}_{1} k^{1}$ lower sandstone member and also the $\mathrm{S}_{1} k^{3-1}$ lower sandstone section (Ma et al, 2012).

The overlying $\mathrm{S}_{1} t^{1}$ lower red mudstone member of the Tataertag Formation, $\mathrm{S}_{1} k^{2}$ middle mudstone member and $\mathrm{S}_{1} k^{3-2}$ middle mudstone section of the Kelpintag Formation constitute three sets of effective regional seals for Silurian oil reservoirs within the Shuntuoguole Low Uplift (Quan et al, 2008; Jiang et al, 2008; Fig. 2).

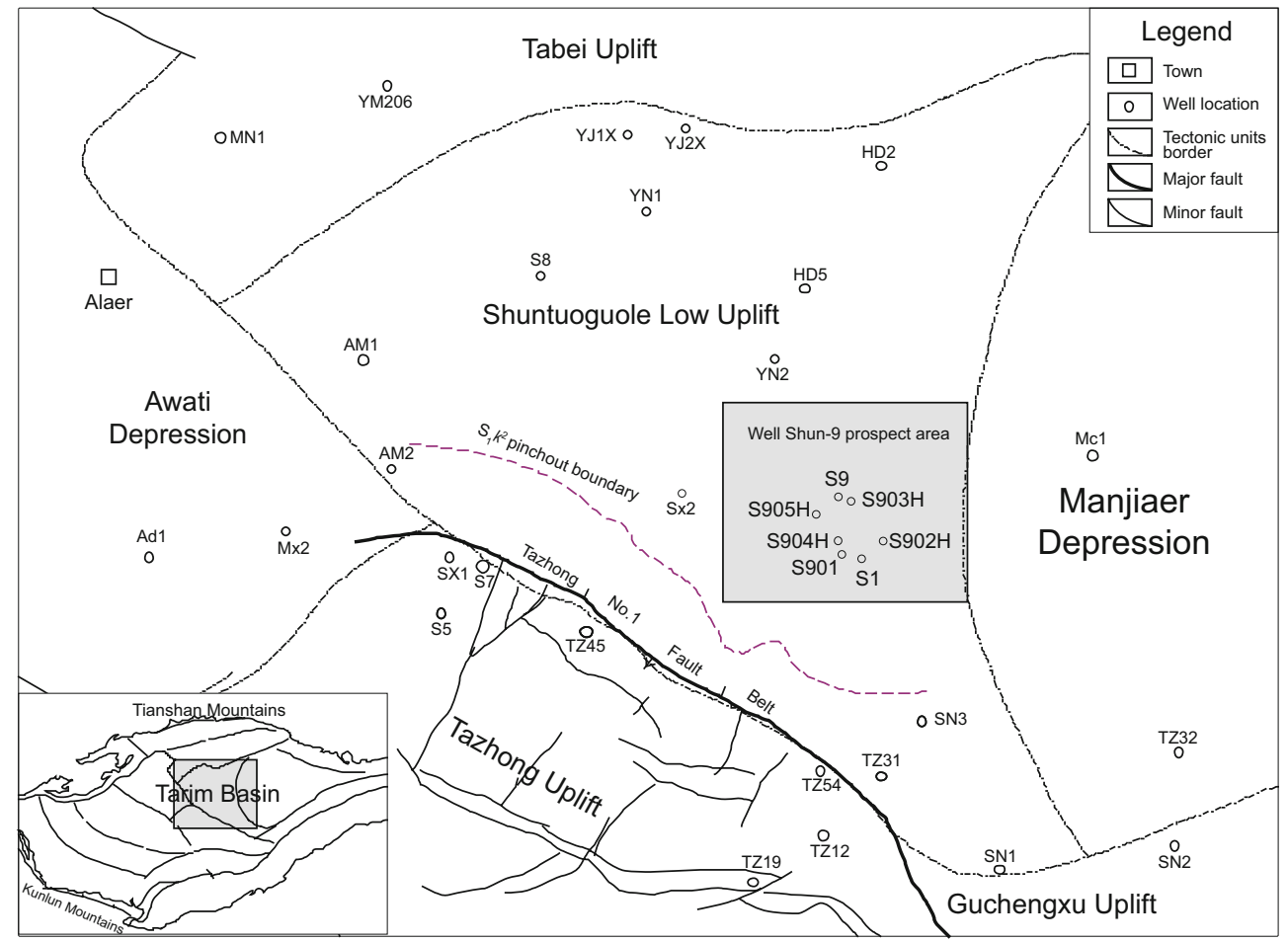

Fig. 1 Geological map of the Shuntuoguole Low Uplift

\section{Experimental}

Oil sands were Soxhlet-extracted with chloroform $\left(\mathrm{CHCl}_{3}\right)$. The oil sand/source rock extracts and oils were deasphalted using $n$-hexane, and then fractionated using column chromatography (silica gel vs. alumina $3: 1$ ) into saturate, aromatic and NSO fractions by sequential elution with $n$-hexane, toluene and chloroform.

Gas chromatography (GC) of the saturate fractions was performed using an Agilent Model 6890 gas chromatograph equipped with a fused silica column (HP-1, $30 \mathrm{~m} \times 0.25 \mathrm{~mm}$ i.d.). The oven temperature program was from $100{ }^{\circ} \mathrm{C}(1 \mathrm{~min})$ to $300{ }^{\circ} \mathrm{C}$ (held $10 \mathrm{~min}$ ) at $4{ }^{\circ} \mathrm{C} / \mathrm{min}$. Helium was used as carrier gas.

GC-mass spectrometry (GC-MS) analysis of saturated and aromatic fractions were conducted using an Agilent Model 6890 gas chromatograph fitted with a DB-5MS capillary. The GC temperature operating conditions for the saturated fraction were: $100{ }^{\circ} \mathrm{C}(1 \mathrm{~min})$ to $220{ }^{\circ} \mathrm{C}$ at $4{ }^{\circ} \mathrm{C} /$ min and, then to $300{ }^{\circ} \mathrm{C}$ (held $5 \mathrm{~min}$ ) at $2{ }^{\circ} \mathrm{C} / \mathrm{min}$; for the aromatic fraction were: $80^{\circ} \mathrm{C}(1 \mathrm{~min})$ to $300{ }^{\circ} \mathrm{C}$ (held $15 \mathrm{~min}$ ) at $3{ }^{\circ} \mathrm{C} / \mathrm{min}$. Saturated and aromatic hydrocarbon biomarker parameters were calculated from integrated peak areas on the mass chromatograms.
The stable carbon isotopic compositions $\left(\delta^{13} \mathrm{C}\right)$ of oils/ extracts and their fractions were analyzed on a Thermoscience Model MAT 253 IR-MS. The oils/extracts and their fractions were burned to produce individual $\mathrm{CO}_{2}$ peaks on a Flash HT copper oxide reaction furnace at $980{ }^{\circ} \mathrm{C}$. Their $\delta^{13} \mathrm{C}$ values were measured by integration of the masses 44,45 and 46 ion current counts of $\mathrm{CO}_{2}$ peaks. $\mathrm{A} \mathrm{CO}_{2}$ reference gas with known $\delta^{13} \mathrm{C}_{\mathrm{PDB}}$ value was pulsed into the mass spectrometer. The $\delta^{13} \mathrm{C}$ values of the oils/extracts and their fractions were reported in the $\delta$ notation relative to the reference gas. The average values of at least two runs for each sample were reported and only results with a standard deviation of less than $0.3 \%$ were used.

\section{Results and discussion}

\subsection{Oil physical properties and gross composition}

The Silurian oil reservoir in the Well Shun-9 prospect area has a regular variation in oil physical properties and gross composition as follows. From Well Shun-9, via Well Shun-901, to Well Shun-902H, the oil density, viscosity, sulfur content as well as aromatic and asphaltene contents are gradually increasing, whereas their saturate contents and 


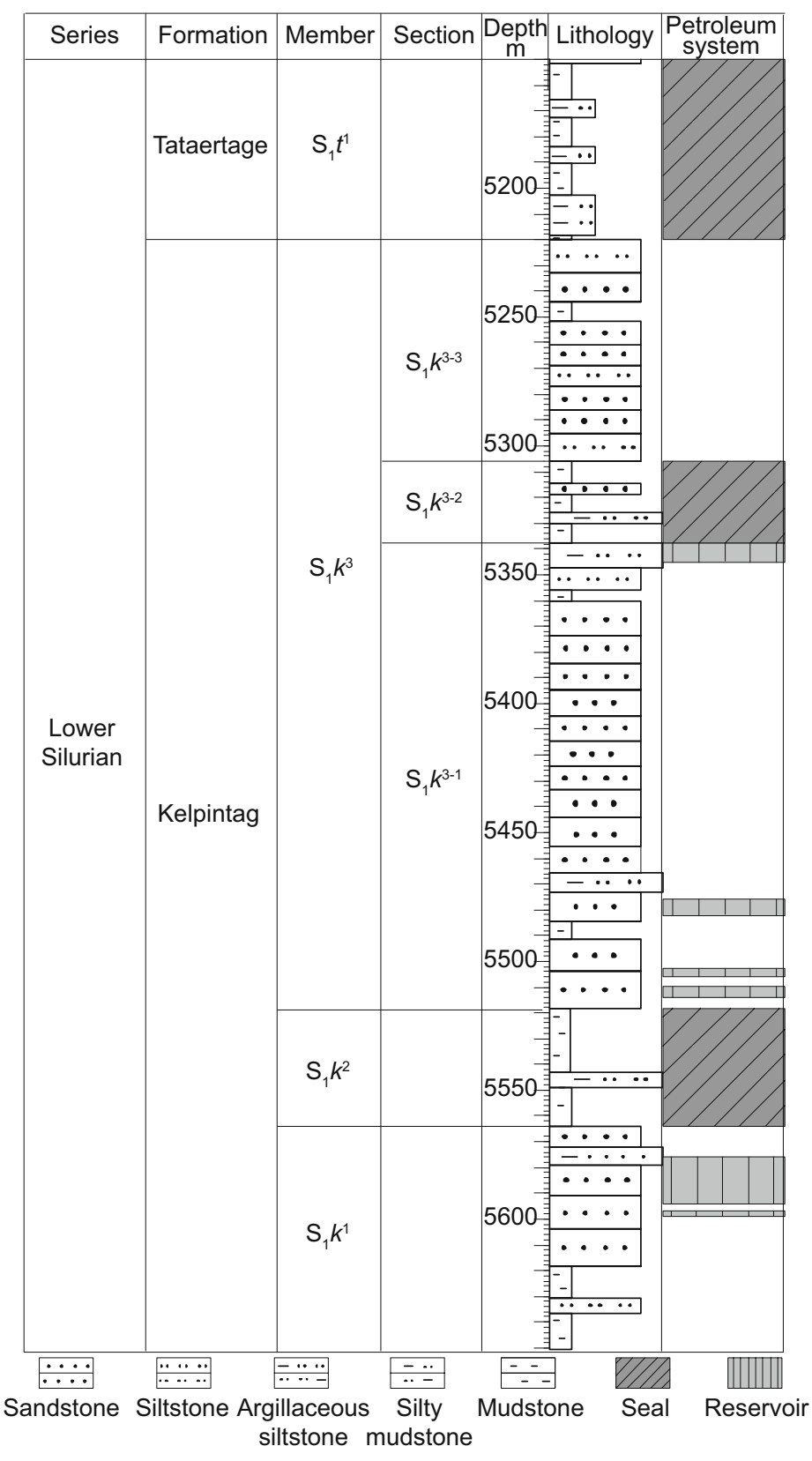

Fig. 2 Generalized Lower Silurian stratigraphy in the Shuntuoguole Low Uplift

saturates to aromatics ratios seem to be decreasing, so that the reservoir oils vary from regular black oil in Wells Shun9 and Shun-901 to heavy oil in Well Shun-902H. Moreover, the wax content also shows a wide range in different samples, varying from $3.0 \%$ to $16.1 \%$ (Table 1 ). The gradual variations in oil physical properties and gross compositions support an increased biodegradation degree from the oil in Well Shun-9, via Well Shun-901, to Well Shun-902H.

As a whole, all the gross compositions of oil sands show relatively low saturate contents as well as high aromatic, NSO-compound and asphaltene contents owing to the adsorptive effect in the sandstone reservoir (Table 1).

Due to the disparity in total seal thickness and secondary alteration (biodegradation), the gross composition of oil sands from different intervals is also varied. Oil sands in the shallower $\mathrm{S}_{1} k^{3-1}$ lower sandstone section (about 5,303-
5,316 m deep) appear lower saturate content (28.6\%-31.8\%) and saturates to aromatics ratio (1.1-1.9) as well as higher asphaltene content $(32.3 \%-45.7 \%)$. On the contrary, the deeper $\mathrm{S}_{1} k^{1}$ lower sandstone member oil sands (around 5,500$5,568 \mathrm{~m}$ in depth) have higher saturate content $(54.8 \%-62.6 \%)$ and saturates to aromatics ratio $(2.2-3.0)$ as well as lower asphaltene contents $(6.5 \%-7.9 \%$, Table 1$)$.

\subsection{Hydrocarbon composition}

\subsubsection{Acyclics}

The $n$-alkane series of the Silurian oils in the $\mathrm{S}_{1} k^{1}$ lower sandstone member reservoir occur with a unimodal distribution pattern, with maximum carbon number at $n \mathrm{C}_{14}$ or $n \mathrm{C}_{15}$ and an $n \mathrm{C}_{21}-/ n \mathrm{C}_{22}+$ ratio of 1.71-3.23, suggesting a high maturity level. In addition, all their $\mathrm{GC}$ traces have a baseline "hump" resulting from unresolved complex mixture (UCM) in the oil, but only the heavy oil of Well Shun-902H shows a more obvious UCM "hump", indicating the disparity of the biodegradation effect (Fig. 3(a)-(c)).

As for the oil sand extracts in the deeper $\mathrm{S}_{1} k^{1}$ lower sandstone member reservoir, their $n$-alkane series almost have a similar unimodal distribution pattern with the oils, with an average $n \mathrm{C}_{21}-/ n \mathrm{C}_{22}+$ ratio of 1.72 , while the maximum carbon number has been transferred to $n \mathrm{C}_{17}$ or $n \mathrm{C}_{19}$, showing an adsorption effect of reservoir rock (Fig. 3(d)-(f), Table 2).

In the oil sand extracts for the reservoir rocks of the shallower $\mathrm{S}_{1} k^{3-1}$ sandstone section, however, most $n$-alkanes have been moved out and all their GC traces show a predominant UCM "hump" as expected for severely biodegraded oils (Connan, 1984; Fig. 3(g), (h)).

Besides $n$-alkanes, pristine $(\mathrm{Pr})$ and phytane $(\mathrm{Ph})$ are also detected in both oils and oil sand extracts in the Well Shun-9 prospect area (Fig. 3), all of which show an equal abundance tendency with the $\mathrm{Pr} / \mathrm{Ph}$ ratio ranging from 0.84 to 0.98 (Table 2), revealing similar sedimentary and diagenesis environments of the oil source bed. Moreover, as shown in Fig. 4, the $\mathrm{Pr} / \mathrm{Ph}$ ratios of our analyzed samples fall into the ratio range of Tahe oils, which are derived from Upper Ordovician source rocks (Wang et al, 2006).

\subsubsection{Terpanoids}

As predominant terpanoid components of the Silurian oils and oil sands in the well Shun-9 prospect area, tricyclic terpane series have a much higher abundance than the pentacyclic hopane series, with the tricyclics to hopanes ratios (TT/H) from 1.58-3.59 (Table 2). In tricyclics, the $\mathrm{C}_{23}$ tricyclic terpane is predominant over $\mathrm{C}_{21}$ tricyclic terpane, resulting in $\mathrm{C}_{21} / \mathrm{C}_{23}$ tricyclic terpane ratio $<1.0\left(\mathrm{C}_{21} / \mathrm{C}_{23} \mathrm{TT}\right.$, Table 2, Fig. 5), which can be well correlated with the previously analyzed oil source rock of the $\mathrm{O}_{3} l$ Lianglitage Formation instead of the Cambrian source rock in the Tarim Basin (Fig. 5(i), (j)).

$\mathrm{C}_{27}$ to $\mathrm{C}_{35}$ (no $\mathrm{C}_{28}$ ) hopane series and gammacerane are detected, showing a regular distribution pattern and low gammacerane $/ \mathrm{C}_{30}$ hopane ratio 0.19 in average, in the Silurian oils and oil sands (Fig. 5).

A distinct feature between the samples from different intervals is the relative abundance of 25-norhopanes. 25-norhopanes are absent in the oils and oil sands from the 
Table 1 Basic geochemical data for the Silurian oils and oil sands in the Well Shun-9 prospect area

\begin{tabular}{|c|c|c|c|c|c|c|c|c|c|c|c|c|c|c|c|c|c|c|}
\hline \multirow[b]{2}{*}{ No. } & \multirow[b]{2}{*}{ Well } & \multirow{2}{*}{$\begin{array}{l}\text { Depth } \\
\mathrm{m}\end{array}$} & \multirow{2}{*}{$\begin{array}{c}\text { Mem./ } \\
\text { Sect. }\end{array}$} & \multirow[b]{2}{*}{ Sample } & \multicolumn{4}{|c|}{ Physical properties } & \multicolumn{5}{|c|}{ Gross composition } & \multicolumn{5}{|c|}{ Isotopic composition $\delta^{13} \mathrm{C}, \% 0_{\mathrm{PDB}}$} \\
\hline & & & & & $\begin{array}{c}\text { Density } \\
\mathrm{g} / \mathrm{cm}^{3}\end{array}$ & $\begin{array}{c}\text { Viscosity } \\
\mathrm{mPa} \cdot \mathrm{s}\end{array}$ & $\begin{array}{c}\text { Sulfur } \\
\%\end{array}$ & $\begin{array}{c}\text { Wax } \\
\%\end{array}$ & $\begin{array}{c}\text { Sat } \\
\%\end{array}$ & $\begin{array}{c}\text { Aro } \\
\%\end{array}$ & $\begin{array}{c}\text { NSO } \\
\%\end{array}$ & $\begin{array}{c}\text { Asp } \\
\%\end{array}$ & Sat/Aro & $\begin{array}{c}\text { Oil/ } \\
\text { Extract }\end{array}$ & Sat & Aro & NSO & Asp \\
\hline 1 & Shun-9 & $5560-5583$ & & Regular & 0.868 & 16.5 & 0.46 & 16.1 & 76.3 & 15.9 & 4.9 & 2.9 & 4.8 & -32.3 & -32.3 & -31.8 & -31.9 & -32.1 \\
\hline 2 & Shun-901 & 5496-5504 & $\mathrm{S}_{1} k^{1}$ & oil & 0.876 & 22.8 & 0.46 & 2.98 & 67.2 & 18.6 & 6.8 & 7.4 & 3.6 & -31.9 & -31.9 & -31.8 & -31.5 & -32.1 \\
\hline 3 & Shun-902H & $5865-6302$ & & $\begin{array}{c}\text { Heavy } \\
\text { oil }\end{array}$ & 0.925 & 871.9 & 0.75 & 6.05 & 55.0 & 24.6 & 3.0 & 17.4 & 2.2 & -31.6 & -31.5 & -31.8 & -31.3 & -32.2 \\
\hline 4 & Shun-1 & 5316 & $\mathrm{~S}_{1} k^{3-1}$ & \multirow{5}{*}{$\begin{array}{c}\text { Oil } \\
\text { sand }\end{array}$} & -- & -- & -- & -- & 28.6 & 24.8 & 14.3 & 32.3 & 1.1 & -31.8 & -31.7 & -31.8 & -32.0 & -32.3 \\
\hline 5 & Shun-902H & 5303 & & & -- & -- & -- & -- & 31.8 & 16.5 & 6.0 & 45.7 & 1.9 & -32.2 & -32.2 & -32.2 & -32.1 & -32.9 \\
\hline 6 & Shun-901 & 5500 & & & -- & -- & -- & -- & 57.4 & 25.7 & 9.1 & 7.9 & 2.2 & -31.7 & -32.2 & -31.9 & -31.4 & -31.2 \\
\hline 7 & Shun-902H & 5517 & $\mathrm{~S}_{1} k^{1}$ & & -- & -- & -- & -- & 54.8 & 23.0 & 11.1 & 11.1 & 2.4 & -32.1 & -31.3 & -32.2 & -32.2 & -32.6 \\
\hline 8 & Shun-904H & 5568 & & & -- & -- & -- & -- & 62.6 & 21.0 & 9.9 & 6.5 & 3.0 & -31.7 & -31.5 & -31.3 & -31.4 & -31.8 \\
\hline
\end{tabular}

Notes: Sat, saturated fraction; Aro, aromatic fraction; NSO, NSO-compound fraction; Asp, asphaltene fraction

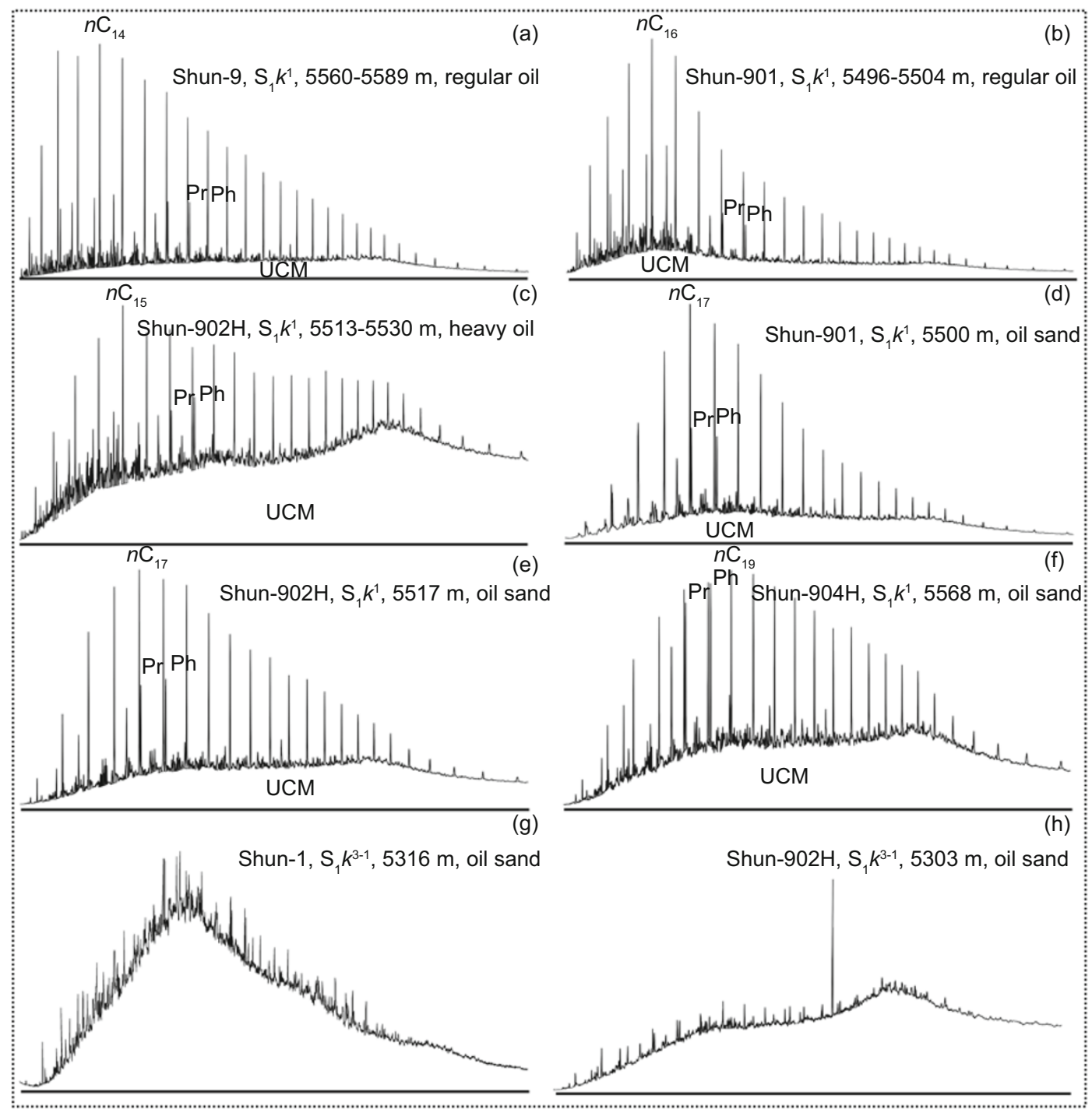

Fig. 3 Gas chromatograms of saturated hydrocarbon fraction

Notes: $\mathrm{Pr}$, pristane; $\mathrm{Ph}$, phytane; $n \mathrm{C}_{i}$, normal alkanes; $i$, molecular carbon number; UCM, unresolved complex mixture; *, internal standard

$\mathrm{S}_{1} k^{1}$ member, while they are abundant in the oil sands from the $\mathrm{S}_{1} k^{3-1}$ interval, with the ratio of $\mathrm{C}_{29} 25$-norhopane $/ \mathrm{C}_{30}$-hopane from 0.36 to 0.41 . As shown in $\mathrm{m} / \mathrm{z} 177$ mass chromatograms,
$\mathrm{C}_{29}$ 25-norhopane and $\mathrm{C}_{28} 25,30$-bisnorhopane are the dominant 25-demethylated compound in the oil sands from the $\mathrm{S}_{1} k^{3-1}$ interval, but a whole distribution of 25-norhopanes 
Table 2 Basic geochemical parameters for the Silurian oils and oil sands in the Well Shun-9 prospect area

\begin{tabular}{|c|c|c|c|c|c|c|c|c|c|c|c|c|c|c|c|c|c|c|c|c|c|c|}
\hline \multirow{3}{*}{ No. } & \multirow{3}{*}{ Well } & \multirow{3}{*}{$\begin{array}{l}\text { Depth } \\
\text { m }\end{array}$} & \multirow{3}{*}{$\begin{array}{l}\text { Mem./ } \\
\text { Sect. }\end{array}$} & \multirow{3}{*}{ Sample } & \multicolumn{4}{|c|}{ Acyclic alkanes } & \multicolumn{5}{|c|}{ Terpanoids } & \multicolumn{5}{|c|}{ Steroids } & \multicolumn{4}{|c|}{ Polyaromatic hydrocarbons } \\
\hline & & & & & \multirow{2}{*}{$\begin{array}{l}n \mathrm{C}_{21^{-}}- \\
n \mathrm{C}_{22}+\end{array}$} & \multirow{2}{*}{$\mathrm{Pr} / \mathrm{Ph}$} & \multirow{2}{*}{$\begin{array}{c}\mathrm{Pr} / \\
n \mathrm{C}_{17}\end{array}$} & \multirow{2}{*}{$\begin{array}{l}\mathrm{Ph} / \\
n \mathrm{C}_{18}\end{array}$} & \multirow{2}{*}{$\begin{array}{c}\mathrm{C}_{21} / \mathrm{C}_{23} \\
\mathrm{TT}\end{array}$} & \multirow{2}{*}{$\begin{array}{c}\mathrm{Ts} / \\
(\mathrm{Ts}+\mathrm{Tm})\end{array}$} & \multirow{2}{*}{$\begin{array}{c}\mathrm{TT} / \\
\mathrm{H}\end{array}$} & \multirow{2}{*}{$\begin{array}{c}\mathrm{G} / \\
\mathrm{C}_{30} \mathrm{H}\end{array}$} & \multirow{2}{*}{$\begin{array}{c}\mathrm{C}_{29} 25- \\
\mathrm{NH} / \\
\mathrm{C}_{30} \mathrm{H}\end{array}$} & \multicolumn{3}{|c|}{$\begin{array}{c}\text { Regular } \\
\text { steranes, \% }\end{array}$} & \multirow{2}{*}{ Dia/RS } & \multirow{2}{*}{$\begin{array}{c}\left(\mathrm{C}_{21}+\mathrm{C}_{22}\right) \mathrm{P} / \\
\left(\mathrm{C}_{27}-\mathrm{C}_{29}\right) \\
\mathrm{RS}\end{array}$} & \multicolumn{3}{|c|}{ FL-DBT-DBF, $\%$} & \multirow{2}{*}{$\begin{array}{c}\text { 4-/1- } \\
\text { MDBT }\end{array}$} \\
\hline & & & & & & & & & & & & & & $\mathrm{C}_{27}$ & $\mathrm{C}_{28}$ & $\mathrm{C}_{29}$ & & & FL & DBT & DBF & \\
\hline 1 & Shun-9 & $5560-5583$ & & Regular & 2.55 & 0.84 & 0.3 & 0.43 & 0.43 & 0.56 & 1.84 & 0.35 & -- & 0.34 & 0.2 & 0.46 & 0.28 & 0.2 & 16.6 & 20.7 & 62.7 & 6.99 \\
\hline 2 & Shun-901 & $5496-5504$ & $\mathrm{~S}_{1} k^{1}$ & oil & 3.23 & 0.95 & 0.52 & 0.63 & 0.55 & 0.46 & 3.59 & 0.15 & -- & 0.47 & 0.2 & 0.33 & 0.28 & 0.34 & 57.3 & 24.7 & 18.0 & 4.57 \\
\hline 3 & Shun-902H & $5865-6302$ & & $\begin{array}{c}\text { Heavy } \\
\text { oil }\end{array}$ & 1.71 & 0.92 & 0.44 & 0.59 & 0.5 & 0.44 & 2.86 & 0.18 & -- & 0.36 & 0.2 & 0.44 & 0.34 & 0.3 & 64.9 & 21.7 & 13.4 & 3.08 \\
\hline 4 & Shun-1 & 5316 & S, $k$ & \multirow{5}{*}{$\begin{array}{c}\text { Oil } \\
\text { sand }\end{array}$} & 1.48 & 0.65 & 0.69 & 1.01 & 0.51 & 0.35 & 1.84 & 0.16 & 0.41 & 0.2 & 0.41 & 0.39 & 0.58 & 0.21 & 77.3 & 13.9 & 8.80 & -- \\
\hline 5 & Shun- $902 \mathrm{H}$ & 5303 & & & 2.34 & 0.86 & 0.59 & 0.86 & 0.58 & 0.37 & 2.51 & 0.17 & 0.36 & 0.39 & 0.19 & 0.43 & 0.24 & 0.31 & 91.5 & 4.30 & 4.20 & -- \\
\hline 6 & Shun-901 & 5500 & & & 1.86 & 0.94 & 0.53 & 0.55 & 0.48 & 0.5 & 1.58 & 0.29 & -- & 0.31 & 0.23 & 0.46 & 0.22 & 0.19 & 92.1 & 4.66 & 3.24 & -- \\
\hline 7 & Shun- $902 \mathrm{H}$ & 5517 & $\mathrm{~S}_{1} k^{1}$ & & 1.38 & 0.98 & 0.44 & 0.56 & 0.49 & 0.38 & 2.62 & 0.15 & -- & 0.43 & 0.21 & 0.36 & 0.27 & 0.22 & 87.8 & 7.10 & 5.10 & -- \\
\hline 8 & Shun-904H & 5568 & & & 1.39 & 0.91 & 1.07 & 1.12 & 0.49 & 0.46 & 2.68 & 0.12 & -- & 0.35 & 0.21 & 0.44 & 0.3 & 0.32 & 74.2 & 17.2 & 8.60 & -- \\
\hline
\end{tabular}

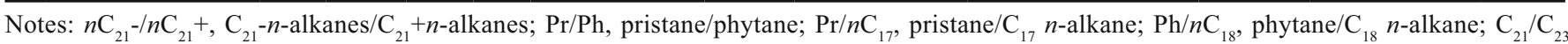
$\mathrm{TT}, \mathrm{C}_{21}$ tricyclic terpane/C $\mathrm{C}_{23}$ tricyclic terpane; Ts/(Ts+Tm), $\mathrm{C}_{27} 18 \alpha(\mathrm{H})$-trisnor-neohopane/C 27 [18 $\alpha(\mathrm{H})$-trisnor-neohopane $+17 \alpha(\mathrm{H})$-trisnor-hopane]; $\mathrm{TT} / \mathrm{H}$, tricyclic terpanes/hopanes; $\mathrm{G} / \mathrm{C}_{30} \mathrm{H}$, gammacerane/ $\mathrm{C}_{30}$ hopane; $\mathrm{C}_{29} 25-\mathrm{NH} / \mathrm{C}_{30} \mathrm{H}, \mathrm{C}_{29}$ 25-norhopane/ $\mathrm{C}_{30}$ hopane; Dia/RS, diasteranes/regular steranes; $\left(\mathrm{C}_{21}+\mathrm{C}_{22}\right) \mathrm{P} /\left(\mathrm{C}_{27}-\mathrm{C}_{29}\right) \mathrm{RS}, \mathrm{C}_{21}+\mathrm{C}_{22}$ pregnanes/ $\mathrm{C}_{27}-\mathrm{C}_{29}$ regular steranes; FL, fluorene; DBT, dibenzothiophene; DBF, dibenzofuran; 4-/1-MDBT, 4-/1-methyldibenzothiophene

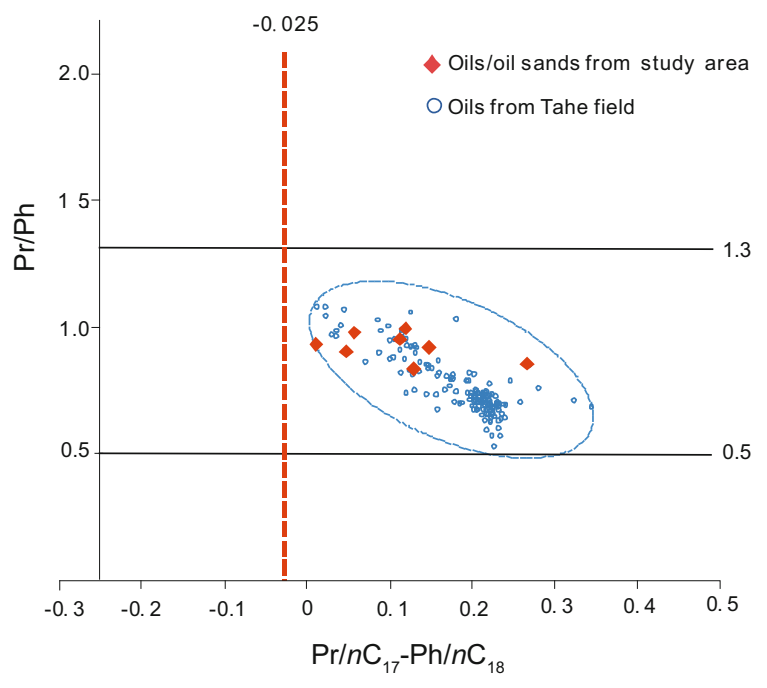

Fig. 4 Plot of $\mathrm{Pr} / \mathrm{Ph}$ ratios vs. $\left(\mathrm{Pr} / n \mathrm{C}_{17}-\mathrm{Ph} / n \mathrm{C}_{18}\right)$ values

Notes: $\mathrm{Pr}$, pristane; $\mathrm{Ph}$, phytane; $n \mathrm{C}_{i}$, normal alkanes; $i$, molecular carbon number

paralleling the $17 \alpha(\mathrm{H}), 21 \beta(\mathrm{H})$-hopanes (from $\mathrm{C}_{29}$ up to $\mathrm{C}_{33}$ ) is present in low concentration (Fig. 6). 25-Norhopanes are produced when all straight-chain and isoprenoid alkanes, and most of the bicyclic alkanes have already been removed (Philp et al, 1981; 1982), so they are taken as evidence of extensive bacterial activity.

\subsubsection{Steroids}

Usually steroids consist of $\mathrm{C}_{27}-\mathrm{C}_{29}$ regular sterane series and $\mathrm{C}_{21}-\mathrm{C}_{22}$ pregnanes. In the Silurian oils and oil sands, the steroids show a relatively high abundance of $\mathrm{C}_{21}-\mathrm{C}_{22}$ pregnanes in comparison with $\mathrm{C}_{27}-\mathrm{C}_{29}$ regular steranes, and the $\mathrm{C}_{21}-\mathrm{C}_{22}$ pregnanes to $\mathrm{C}_{27}-\mathrm{C}_{29}$ steranes ratio $\left[\left(\mathrm{C}_{21}+\mathrm{C}_{22}\right) \mathrm{P} /\right.$ $\left(\mathrm{C}_{27}-\mathrm{C}_{29}\right) \mathrm{Rs}$ ] ranges from 0.19 to 0.34 with 0.27 in average. Moreover, the distribution of $\mathrm{C}_{27}-\mathrm{C}_{29}$ regular steranes abundance appears a $\mathrm{C}_{27}>\mathrm{C}_{28}<\mathrm{C}_{29}$ " $\mathrm{V}$ " pattern, in which the
$\mathrm{C}_{28}$ steranes would be less than $25 \%$ in relative abundance, and diasterane has a relatively high abundance (Fig. 7). The characteristics of "V" pattern $\mathrm{C}_{27}-\mathrm{C}_{29}$ steranes distributions and low relative abundance of $\mathrm{C}_{28} 20 \mathrm{R}$ sterane $(<25 \%)$ are correlated well with the previously analyzed $\mathrm{O}_{3} l$ Lianglitage Formation source rocks and are markedly different from the Cambrian source rocks (Fig. 7(i), (j)).

Furthermore, as shown in Fig. 8, all the Silurian oils and oil sands fall into a tight cluster and have a similar $\mathrm{C}_{27}-\mathrm{C}_{29}$ regular steranes distribution to the Ordovician source rocks previously analyzed.

\subsubsection{Triaromatic steroids}

The $\mathrm{m} / \mathrm{z} 245$ mass chromatograms of aromatic hydrocarbon fractions are shown in Fig. 9, exhibiting the distribution of triaromatic dinosteranes and triaromatic steroids. In all the Silurian oils and oil sands, methyltriaromatic steroids are only present in low concentration, especially triaromatic dinosteroids are absent or only present in trace amount, which can also be well correlated with the previously analyzed $\mathrm{O}_{3} l$ Lianglitage Formation source rocks and apparently different from the Cambrian source rocks in which the triaromatic steroids are abundant especially triaromatic dinosteranes (Fig. 9(i), (j)).

\subsubsection{Polyaromatic hydrocarbons}

Various polyaromatic hydrocarbons have been detected, especially the fluorenes, dibenzothiophenes, and dibenzofurans. Fluorene (FL), dibenzothiophene (DBT) and dibenzofuran (DBF) share a similar molecular structure, so they are considered to have originated from the same precursor and their relative compositions can indicate the primary sedimentary environment (Huang, 1987; Lin et al, 1987). Abundant benzothiophenes in oils have been proposed to indicate an anoxic sedimentary environment, whereas, dominant dibenzofuran represents an oxidative environment (Hughes, 1984).

As shown in Fig. 10, all the analyzed samples, except 


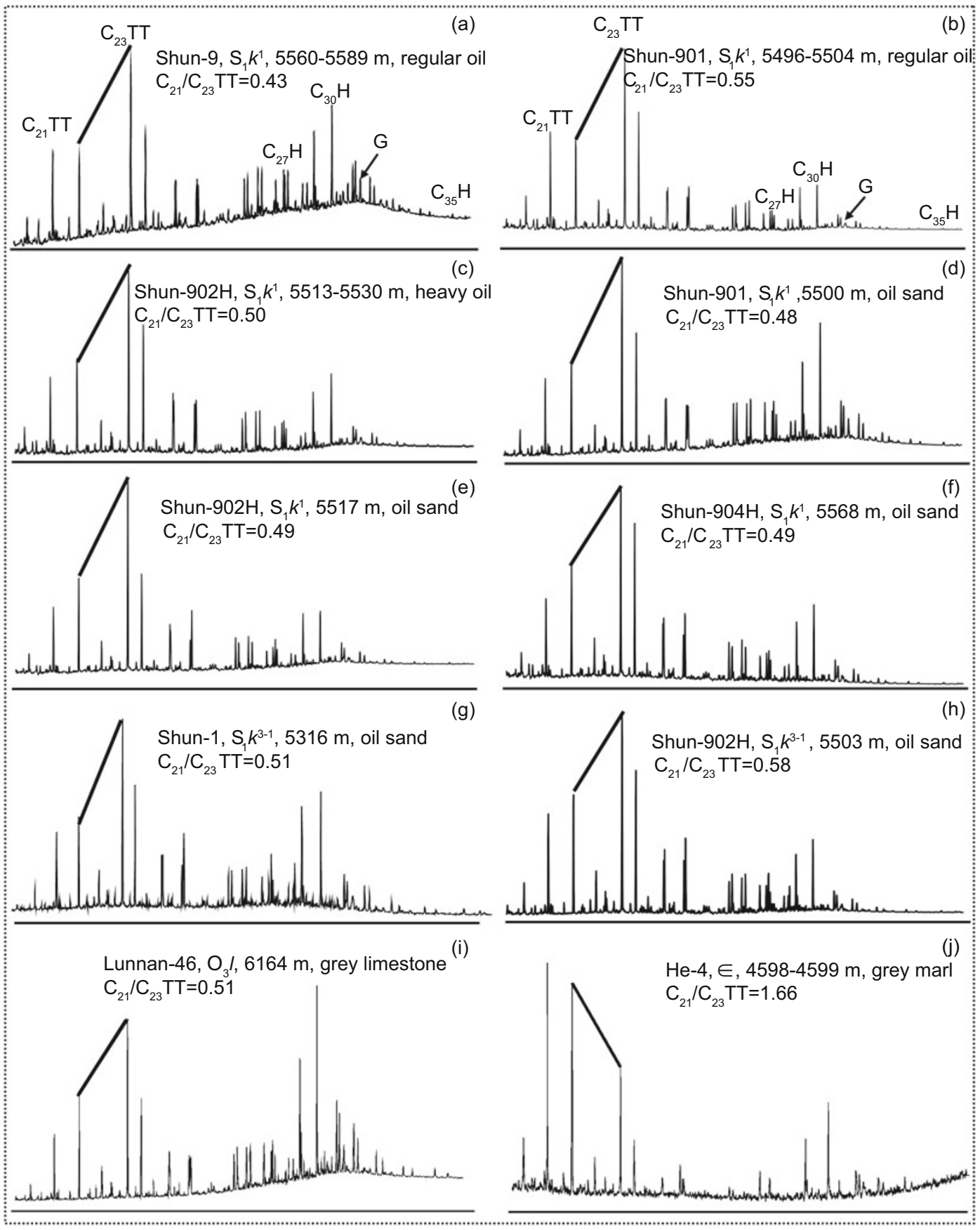

Fig. $5 \mathrm{~m} / \mathrm{z} 191$ mass chromatograms of saturated hydrocarbon fraction, showing the distribution of tricyclic terpane series and hopane series

Notes: TT, tricyclic terpane; $\mathrm{H}$, hopane; $\mathrm{C}_{i}$, molecular carbon number; $\mathrm{G}$, Gammacerane

Shun-1, $\mathrm{S}_{1} k^{3-1}, 5316 \mathrm{~m}$, oil sand

Fig. $6 \mathrm{~m} / \mathrm{z} 177$ mass chromatograms of saturated hydrocarbon fraction, showing the homologous series of 25 -norhopanes Notes: DNH, 25, 30-bisnorhopane; $\mathrm{NH}, 25$-norhopane; $\mathrm{C}_{i}$ : molecular carbon number 


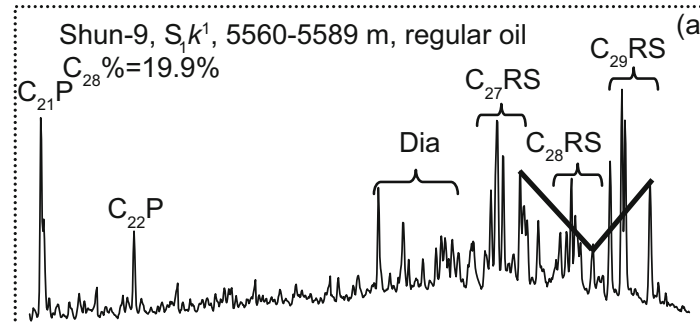

a) Shun-901, $\mathrm{S}_{1} k^{1}, 5496-5504 \mathrm{~m}$, regular oil

(b)

$\mathrm{C}_{21} \mathrm{P}^{28} \%=19.9 \%$

$\mathrm{C}_{21} \mathrm{P} \quad \mathrm{C}_{28} \%=20.1 \%$

Shun-902H, S $k_{1}^{1}, 5513-5530 \mathrm{~m}$, heavy oil $\mathrm{C}_{28} \%=20.4 \%$

(c)
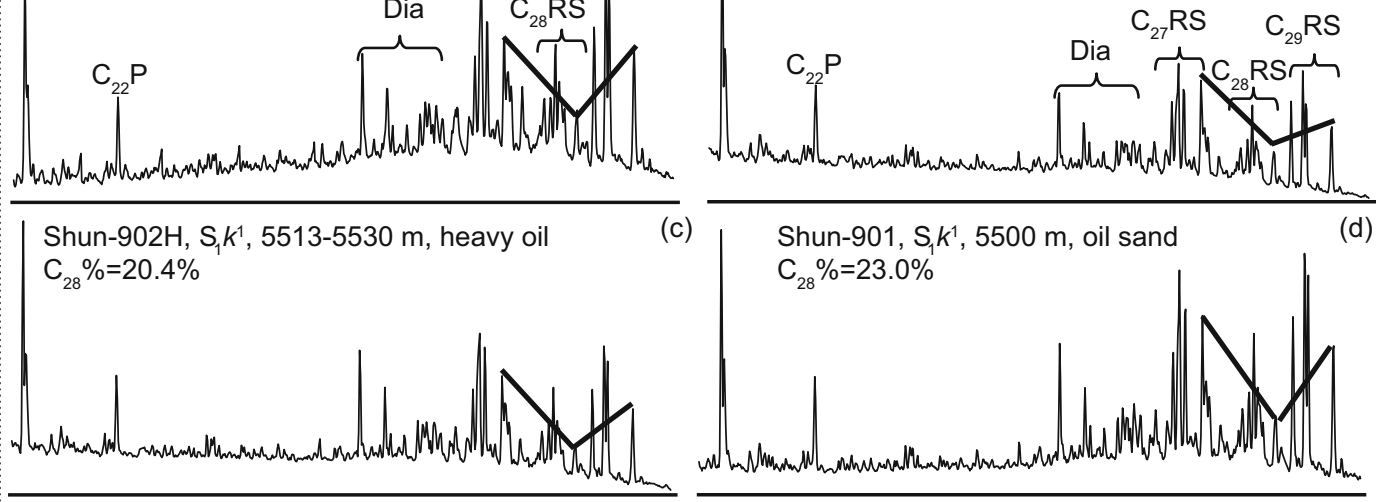

Shun- $902 \mathrm{H}, \mathrm{S}_{1} \mathrm{k}^{1}, 5517 \mathrm{~m}$, oil sand

(e)

Shun- $904 \mathrm{H}, \mathrm{S}_{1} k^{1}, 5568 \mathrm{~m}$, oil sand

(f) $\mathrm{C}_{28} \%=20.9 \%$

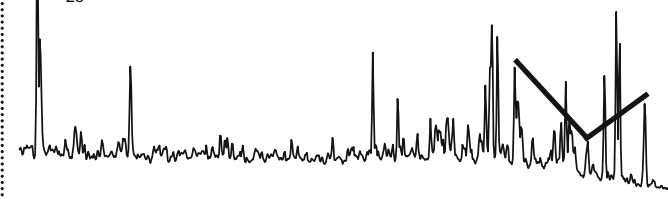

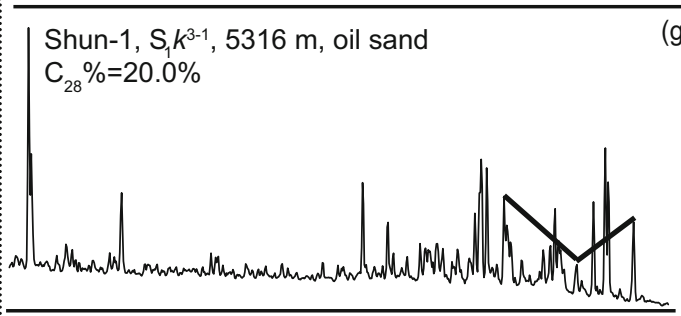

(g) $\mathrm{C}_{28} \%=20.9 \%$

(d)

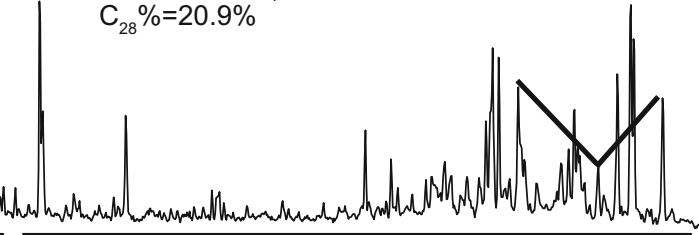

g) Shun-902H, $\mathrm{S}_{1} k^{3-1}, 5303 \mathrm{~m}$, oil sand

(h) $\mathrm{C}_{28} \%=18.9 \%$ Lunnan-46, $\mathrm{O}_{3} \mathrm{l}, 6164 \mathrm{~m}$, grey limestone
$\mathrm{C}_{28} \%=20.5 \%$

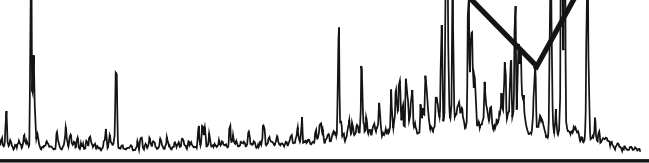

(i)

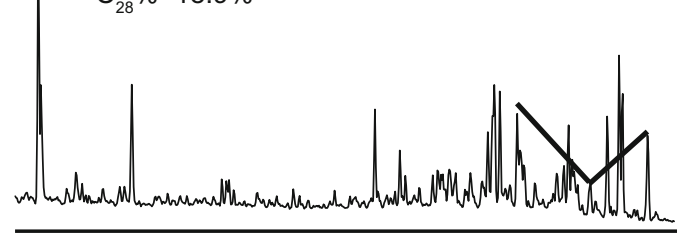

(i)

$\mathrm{He}-4, \in, 4598-4599 \mathrm{~m}$, grey marl $\mathrm{C}_{28} \%=35.0 \%$

(j)

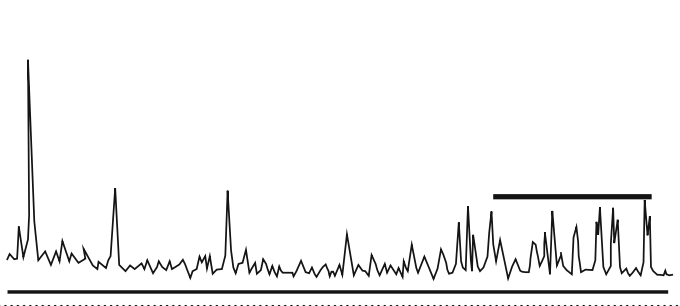

Fig. $7 \mathrm{~m} / \mathrm{z} 217$ mass chromatograms of saturated hydrocarbon fraction, showing the distribution of sterane series Notes: P, pregnane; Dia, diasterane; Rs, regular sterane, $\mathrm{C}_{i}$, molecular carbon number
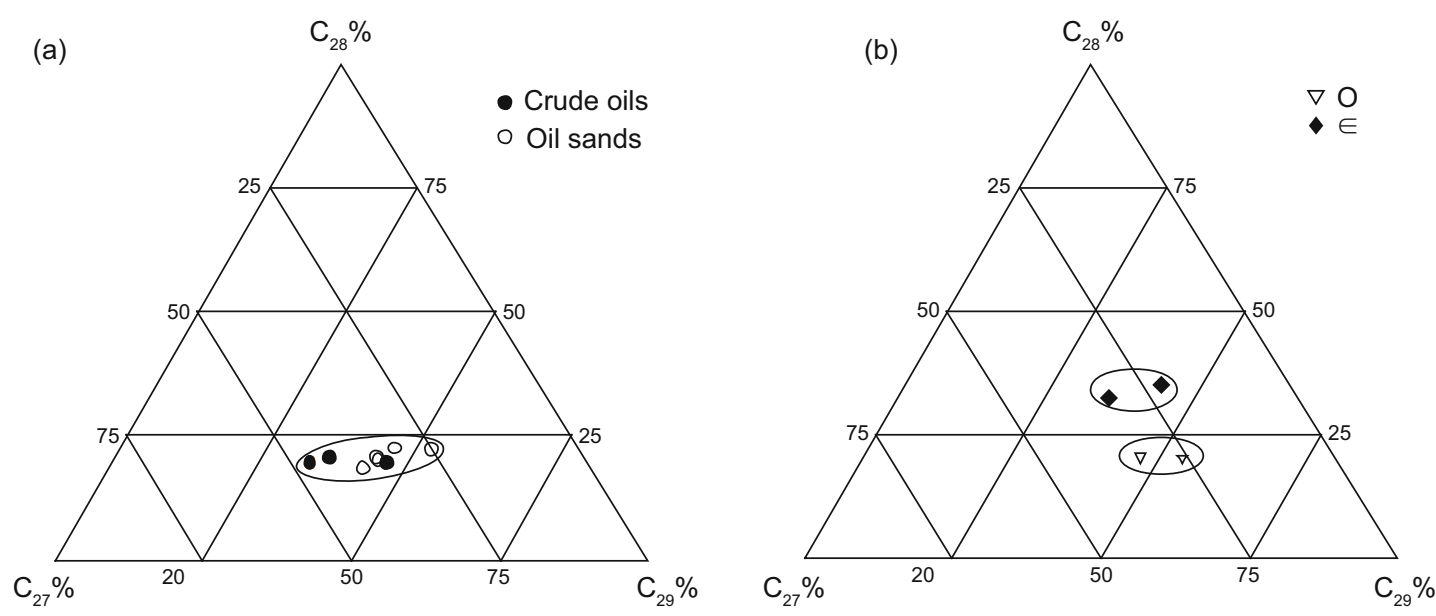

Fig. 8 Ternary plots showing the relative content of $\mathrm{C}_{27}-\mathrm{C}_{29}$ regular steranes

(a) Silurian oils and oil sands from the Well Shun-9 prospect area; (b) previously analyzed oil source rocks in the Tarim Basin 


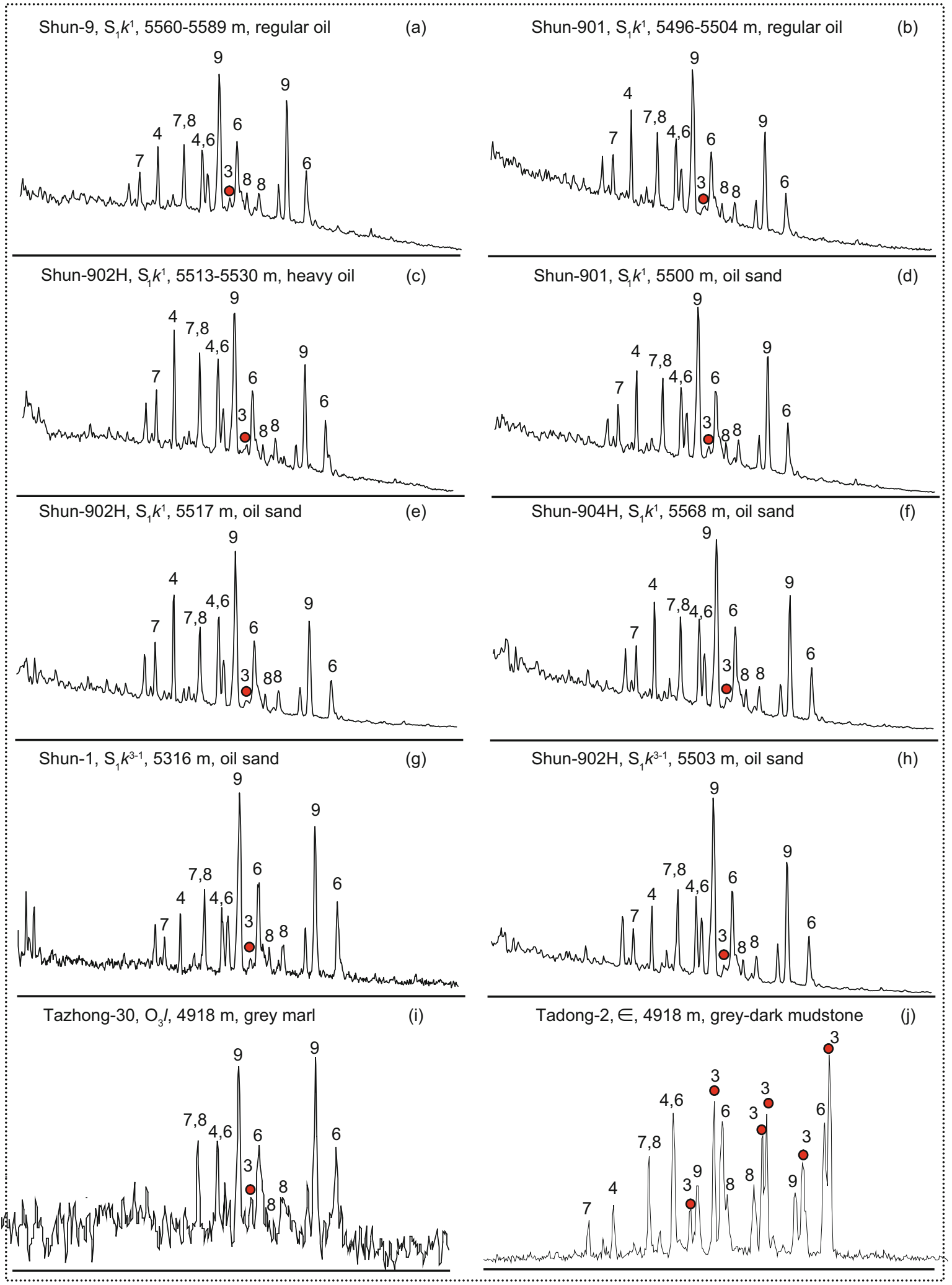

Fig. $9 \mathrm{~m} / \mathrm{z} 245$ mass chromatograms of aromatic hydrocarbon fraction, showing the distribution of triaromatic steroids

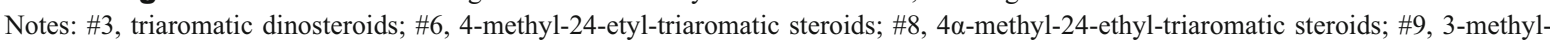
24-ethyl-triaromatic steroids

the oil from S9 well, are characterized by dominant dibenzothiophene (accounting for $56.3 \%-93.4 \%$ of total FL, DBT and DBF, Table 2), indicating a strongly anoxic marine environment. An abnormality of the FL-DBT-DBF composition occurred in the oil from Well Shun-9, in which dibenzofuran accounted for $>60 \%$ of total FL, DBT and DBF. The reason was probably due to contamination by chemical additives added in Well Shun-9 during oil test operation, especially asphaltene dispersants with dominant dibenzofuran (Fig. 10). 


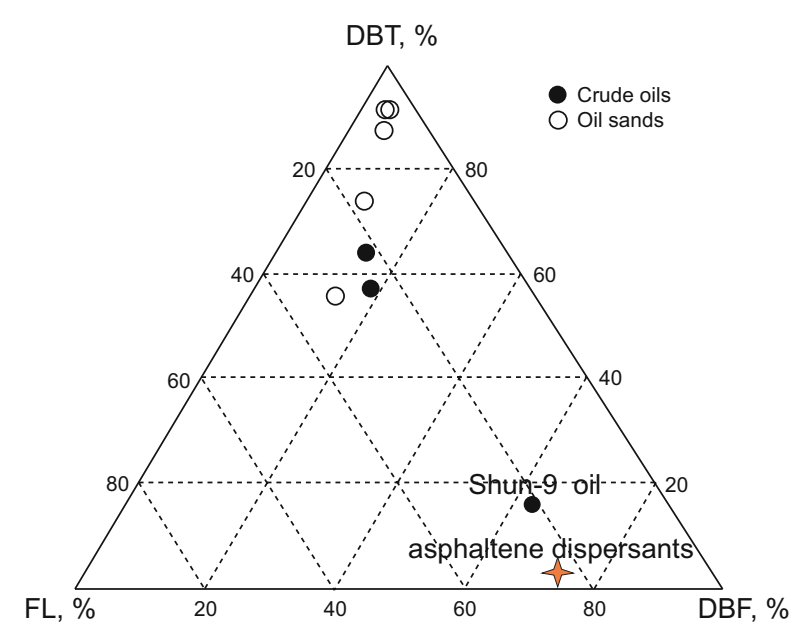

Fig. 10 Ternary plot showing the relative composition of FL-DBT-DBF Notes: FL, fluorene; DBT, dibenzothiophene; DBF, dibenzofuran

\subsection{Stable carbon isotopic composition}

The $\delta^{13} \mathrm{C}$ compositions of oils or extracts can help to determine oil-oil and oil-source rock relationships (Sofer, 1991; Galimov, 2006). The $\delta^{13} \mathrm{C}$ values for the Silurian oils and oil sand extracts range from $-31.6 \%$ to $-32.3 \%$ (Table 1 ) and differ by less than $1 \%$, suggesting that they may have the same genetic origin. The average $\delta^{13} \mathrm{C}$ value for saturate, aromatic, resin and asphaltene fractions is $-31.8 \%$ o, $-31.9 \%$, $-31.8 \%$ and $-32.2 \%$, respectively (Fig. 11). All the Silurian oils/extracts and their fractions are characterized by relative light carbon isotopic composition, which corresponds well with the $\delta^{13} \mathrm{C}$ values of the oil source rocks from the $\mathrm{O}_{3} l$ Lianglitage Formation and is much lighter than those of the Cambrian source rocks (Fig. 11).

\subsection{Direction of oil charge}

As discussed above, the Silurian oils from Wells Shun-9,

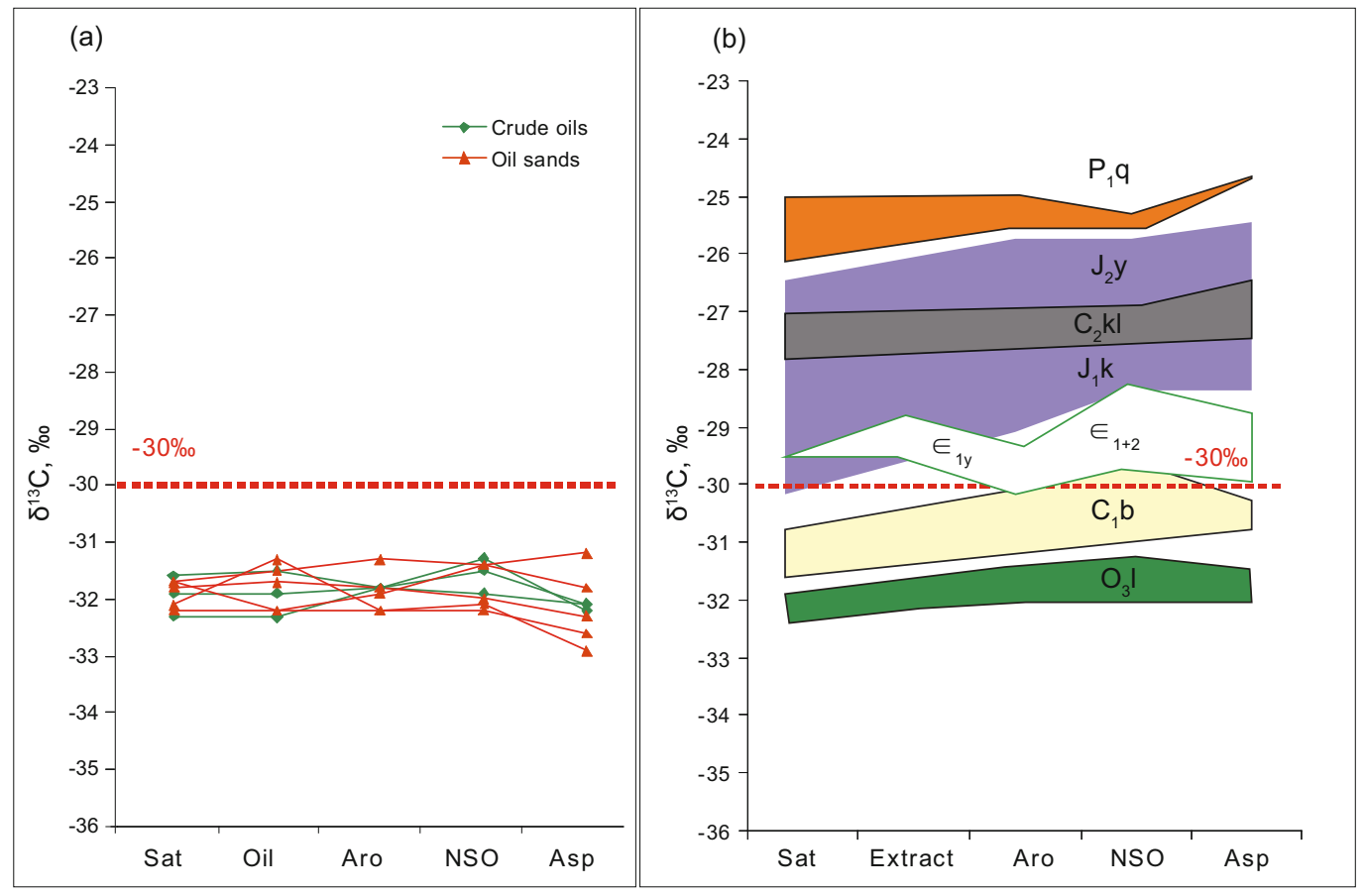

Fig. 11 Stable $\delta^{13} \mathrm{C}$ values for oils/extracts and their fractions (a) Silurian oils and oil sands from the Well Shun-9 prospect area; (b) previously analyzed oil source rocks in the Tarim Basin Notes: Sat, saturated fraction; Aro, aromatic fraction; NSO, NSO-compound; Asp, asphaltene fraction

-901 and $-902 \mathrm{H}$ in the prospect area have similar hydrocarbon and stable carbon isotopic compositions and can be assumed to be from the same oil family, so that the oil reservoir filling direction can be estimated.

Two commonly used reservoir filling tracers are shown in Fig. 12(a), (b), i.e., Ts/(Ts+Tm) and 4-/1-MDBT ratios (Table 2), which can be successfully applied in the Tarim Basin (Wang et al, 2008). Their values all decreased markedly from Well Shun-9, via Well Shun-901, to Well Shun-902H, supporting a general oil filling orientation from northwest to southeast in Well Shun-9 prospect area (Fig. 12). Based on that, we can also conclude that oil source faults should be present to the northwest of our study area.

\section{Conclusions}

1) All the Silurian oils and oil sands from the Well Shun9 prospect area share similar biomarker distributions and $\delta^{13} \mathrm{C}$ values, indicating that they belong to the same oil family and originated from a single source rock. The molecular composition features can be summarized as follows: low $\mathrm{Pr} / \mathrm{Ph}$ and $\mathrm{C}_{21} / \mathrm{C}_{23}$ tricyclic terpane $(<1.0)$ ratios, "V" shape $\mathrm{C}_{27}-\mathrm{C}_{29}$ steranes distributions, low $\mathrm{C}_{28}$-sterane and triaromatic dinosteroid abundances and light $\delta^{13} \mathrm{C}$ values. These are correlated well to those of the previously analyzed $\mathrm{O}_{3} l$ source rocks and are suggested to be indicative of the Upper Ordovician genetic affinity. 

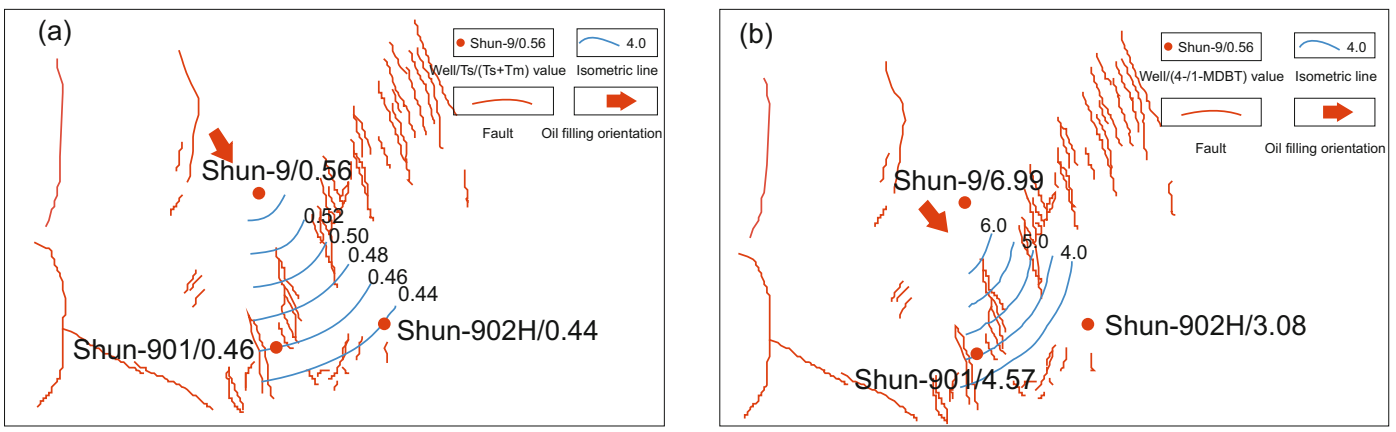

Fig. 12 The oil charging orientation determined by Ts/(Ts+Tm) (a) and 4-/1-methyldibenzothiophene (4-/1-MDBT) ratios (b)

2) Different levels of biodegradation occurred in the oils/ oil sands from different intervals. The oil sands from the $\mathrm{S}_{1} k^{3-1}$ interval of the Kelpintag Formation have been heavily affected by biodegradation. This was evidenced by removal of the most $n$-alkanes, high proportion of NSO+Asp fractions, the magnitude of the "UCM" and presence of 25-norhopanes. Comparatively, the oils and oil sands from the $\mathrm{S}_{1} k^{1}$ member only suffered light biodegradation. The evidence includes the presence of intact $n$-alkanes with slight-moderate "UCM" and absence of 25-norhopanes.

The two oil sands from the $\mathrm{S}_{1} k^{3-1}$ section are devoid of the protection of the $\mathrm{S}_{1} k^{2}$ seal, which may be the principal reason why they suffered heavy biodegradation, while the other samples from the $\mathrm{S}_{1} k^{1}$ member with an $\mathrm{S}_{1} k^{2}$ seal were only lightly biodegraded. It suggests that the $\mathrm{S}_{1} k^{2}$ middle mudstone member of the Kelpintag Formation is significant in the protection of Silurian hydrocarbons.

3) A general oil filling orientation from northwest to southeast was deduced, based on the decreased Ts/(Ts+Tm) and 4-/1-MDBT ratios in the oils from Well Shun-9, via Well Shun-901, to Well Shun 902H.

\section{Acknowledgements}

We would like to thank the Northwest Branch Company, SINOPEC for access to samples and grant support. We also thank Shi Shengbao, Zhu Dan and Zhu Lei for assistance with GC and GC-MS analysis.

\section{References}

Connan J. Biodegradation of crude oils in reservoirs. In: Brooks J and Welte D H (eds.), Advances in Petroleum Geochemistry. London: Academic Press. 1984: 298-335

Galimov E M. Isotope organic geochemistry. Organic Geochemistry. 2006. 37: 1200-1262

Huang G H. The Origin and Geochemical Significance of Fluorene and its Derivatives in Fossil Fuels. Beijing: Science Press. 1987. 211-220 (in Chinese)

Hughes W B. Use of thiophenic organosulfur compounds in characterizing crude oils derived from carbonate versus siliciclastic sources. American Association of Petroleum Geologists, Tulsa. 1984. 18: 181-196

Jia J H, Zhang B M, Zhu S H, et al. Stratigraphy, sedimentary characteristics and lithofacies palaeogeography of the Silurian in
Tarim Basin. Journal of Palaeogeography. 2006. 8(3): 339-351 (in Chinese)

Jiang Z X, Pang X Q, Liu L F, et al. Quantification of the hydrocarbon destroyed by Silurian bituminous sandstone in the Tarim Basin. Science in China (Series D: Earth Sciences). 2008. 38(S1): 89-94 (in Chinese)

Lin R Z, Wang P R, Dai Y J, et al. Petroleum Geochemical Significance of PAH in Fossil Fuel. Beijing: Geological Publishing House. 1987: 129-140 (in Chinese)

Ma Q Y, Sha X G, Li Y L, et al. Characteristics of strike-slip fault and its controlling on oil in Shuntuoguole region, middle Tarim Basin. Petroleum Geology and Experiment. 2012. 34(2): 120-124 (in Chinese)

Philp R P, Gilbert T D and Friedrich J. Bicyclic sesquiterpenoids and diterpenoids in Australian crude oils. Geochimica et Cosmochimica Acta. 1981. 45(7): 1173-1180

Philp R P, Gilbert T D and Friedrich J. Geochemical correlation of Australian crude oils. APEA J. 1982. 22: 188-199

Quan Y K, Hou H B, Qi L X, et al. Analysis of geological conditions and exploration potential of Silurian pools in the Liangshun region, northern slope of Tazhong. Journal of Mineralogy and Petrology. 2008. 28(4): 100-108 (in Chinese)

Sofer Z. Stable isotopes in petroleum exploration. In: Merrill R K (ed.), Source and Migration Processes and Evaluation Techniques. AAPG, Tulsa. 1991: 103-106

Wang C G, Wang T G, Zhang W B, et al. Molecular geochemistry and classifications of genetic types of petroleum from Tahe Oilfield of the Northern Tarim Basin. Acta Sedimentologica Sinica. 2006. 24(6): 900-907 (in Chinese)

Wang T G, He F Q, Wang C J, et al. Oil filling history of the Ordovician oil reservoir in the major part of the Tahe Oilfield, Tarim Basin, NW China. Organic Geochemistry. 2008. 39(11): 1637-1646

Xiong W L, Chen H H, Yun L, et al. Hydrocarbon charging history for Silurian reservoirs of Shuntuoguole block in the north slope of Tazhone Uplift, Tarim Basin: Constraints from fluid inclusion of Well Shun 9. Acta Petrolei Sinica. 2013. 34(2): 239-246 (in Chinese)

Zhai G M and Wang J J. Analysis of petroleum geology in Tazhong region. Acta Petrolei Sinica. 1999. 20(4): 1 - 6 (in Chinese)

Zhang H L, Wang Z M, Zhang R H, et al. Controlling factors of Silurian high-quality reservoirs in Tarim Basin and selection of exploration direction. China Petroleum Exploration. 2004. 9(5): 21-25 (in Chinese)

Zhu R K, Luo P, He D B, et al. Sedimentary facies and models of the Kepingtage Formation of Silurian in Tazhong area, Tarim Basin. Journal of Palaeogeography. 2005. 7(2): 197-205 (in Chinese)

(Edited by Hao Jie) 